\title{
Kaempferol inhibited bovine herpesvirus 1 replication and LPS-induced inflammatory response
}

\author{
L. ZHU' ${ }^{1 *}$, P. WANG ${ }^{1 *}$, W. YUAN ${ }^{2}$, G. ZHU ${ }^{*}$ \\ ${ }^{1}$ College of Veterinary Medicine, Yangzhou University, 48 East Wenhui Road, Yangzhou, Jiangsu, 225009, P. R. China; Jiangsu Co- \\ innovation Center for Prevention and Control of Important Animal Infectious Diseases and Zoonoses, 48 East Wenhui Road, \\ Yangzhou 225009, P. R. China; ${ }^{2}$ Institute of Animal Sciences, Chinese Academy of Agricultural Sciences, No. 2 Yuanmingyuan West \\ Road, Beijing, 100193, P. R. China
}

Received June 19, 2017; revised November 14, 2017; accepted April 11, 2018

\begin{abstract}
Summary. - Plant-derived flavonoids contain large amount of compounds with pharmacological effects. In this study, we showed the compound Kaempferol to have robust antiviral activity against bovine herpesvirus 1 (BoHV-1) replication in vitro. Kaempferol at a concentration of $100 \mu \mathrm{mol} / \mathrm{l}$ completely inhibited viral replication in MDBK cells. It mainly affects the viral replication at the post-entry stages. The inhibition of Akt signaling is a potential mechanism underlying the antiviral effect of Kaempferol. In addition, at a concentration of 25 and $50 \mu \mathrm{mol} / \mathrm{l} \mathrm{Kaempferol} \mathrm{could} \mathrm{significantly} \mathrm{reduce} \mathrm{the} \mathrm{expression} \mathrm{of} \mathrm{inflammatory} \mathrm{mediators} \mathrm{such} \mathrm{as} \mathrm{tumor}$ necrosis factor alpha (TNF- $\alpha$ ), interleukin 8 (IL-8) and macrophage inflammatory protein 1 alpha (MIP-1 $\alpha$ ) in human promonocytic U937 cells-derived macrophages (dU937) in response to lipopolysaccharides (LPS) stimulation. Overall, our results indicated that Kaempferol provides a potent protection against BoHV-1 infection and LPS-induced inflammatory response.
\end{abstract}

Keywords: BoHV-1; inflammation; Kaempferol; cytokine

\section{Introduction}

Bovine herpesvirus 1 (BoHV-1) belongs to the Alphaherpesvirinae subfamily (Tikoo et al., 1995). BoHV-1 acute infection usually results in inflammatory diseases in the upper respiratory tract, nasal cavity and ocular cavity of the cattle (Jones and Chowdhury, 2007; Jones, 2009). BoHV-1 infection suppresses the immune response, resulting in life-threatening bacterial pneumonia, referred to as bovine

*Co-corresponding authors: Liqian Zhu, E-mail: lzhu3596@163. com, Guoqiang Zhu, E-mail: yzgqzhu@yzu.edu.cn. phone: +8651387990797(LQZ), +86514-87972590 (GQZ). "Contributed equally to this work.

Abbreviations: BoHV = bovine herpes virus; dU937 = U937 cellsderived macrophages; hpi = hours post infection; LPS = lipopolysaccharides; MIP-1 $\alpha=$ macrophage inflammatory protein 1 alpha; MOI = multiplicity of infection; PMA = phorbol-12-myristate-13acetate PAA = phosphonoacetic acid; $\mathrm{ROS}=$ reactive oxidative species; TNF- $\alpha=$ tumor necrosis factor alpha; IL- $8=$ interleukin 8 respiratory disease complex (BRDC) (Muylkens et al., 2007). BoHV-1 infections and the virus-induced BRDC inflict a great economic burden to the cattle industry worldwide, which costs the US cattle industry approximately 3 billion dollars annually (Jones and Chowdhury, 2007).

Generally, excessive expression of pro-inflammatory cytokines would exacerbate the tissue damage in the context of numerous microbial infections, e.g. the cytokine storm resulting from influenza virus H1N1 infection is a key factor for severe pneumonia (La Gruta et al., 2007). It has been demonstrated that the inflammatory cytokines such as interleukin 1 beta (IL-1 $\beta$ ), TNF- $\alpha$ and IL-8 promote the development of BRDC (Bielefeldt Ohmann et al., 1991; Malazdrewich et al., 2001). Overproduction of inflammatory cytokines such as IL- $1 \beta$ and TNF- $\alpha$ in serum following BoHV- 1 infection in vivo has been demonstrated (Muylkens et al., 2007; Risalde et al., 2011), which was confirmed by the report that BoHV-1 infection rapidly increases the transcription of IL- $1 \beta$, IL-8 and TNF- $\alpha$ in the primary cell cultures of bovine bronchial epithelial cells (Rivera-Rivas et al., 2009). Thus, targeting 
both viral replication and inflammatory response represents a viable approach for the control of BoHV-1 infection.

We have recently reported that BoHV-1 infection enhanced the production of cellular reactive oxidative species (ROS), which mediate mitochondrial damage, to facilitate viral infection (Zhu et al., 2016). Importantly, the inflammatory mediator ROS could also stimulate LPS-induced inflammatory response (Wang et al., 2017). Increasing evidence suggests that Kaempferol has strong capacity to protect against oxidative stress, e.g. it protects normal lung and liver cells from $\mathrm{H}_{2} \mathrm{O}_{2}$-induced cytotoxicity, ROS formation and mitochondrial membrane potential loss (Kumar et al., 2016). Therefore it is highly possible that Kaempferol may inhibit both BoHV-1 infection and LPS-induced inflammatory response.

In this study, we report that Kaempferol strongly suppresses BoHV-1 productive infection in cell culture, LPSinduced expression of pro-inflammatory cytokine TNF- $\alpha$, and chemokines IL- 8 and MIP-1 $\alpha$ in macrophage-like dU937 cells.

\section{Materials and Methods}

Virus and cell cultures. MDBK cells were maintained in DMEM (Gibco, CA, USA) supplemented with 10\% horse serum (HyClone, Logan, USA), and routinely passaged whenever they became confluent. BoHV-1 of Colorado1 strain was propagated in MDBK cells, aliquoted, titrated and stored at $-70^{\circ} \mathrm{C}$ until use. Human promonocytic cell line U937 cells (purchased from Chinese model culture preservation center, Shanghai, China) were cultured in RPMI 1640 medium (Gibco, CA, USA) containing 10\% FBS (HyClone, Logan, USA). U937 cells were in vitro differentiated into macrophages dU937 by induction with PMA (Sigma, MO, USA) at a concentration of $100 \mathrm{nmol} / \mathrm{l}$ for $48 \mathrm{~h}$.

Reagents and antibodies. Lipopolysaccharides (LPS) (Cat\# L2630), Kaempferol (Cat\# K0133), phorbol-12- myristate-13acetate (PMA) (Cat\# P8139) and phosphonoacetic acid (PAA) (Cat\# 284270) were obtained from Sigma-Aldrich (St. Louis, MO). They were resolved with DMSO and stored at $-70^{\circ} \mathrm{C}$. Antibodies for phospho-Akt (Ser473) (\#9271) and total Akt (\#9272), $\beta$-Actin (\#4970), and horseradish peroxidase (HRP)-conjugated IgG for secondary antibodies were purchased from Cell Signaling Technology (Beverly, MA, USA).

Antiviral activities assay. MDBK cells of $70-80 \%$ confluent in 24-well plates were pretreated with Kaempferol at indicated concentrations for one hour, and infected with BoHV-1 at an MOI of 1 for one hour in the presence of Kaempferol. After washing three times with phosphate-buffered saline (PBS, pH 7.4), fresh medium containing Kaempferol was replaced and cultured for $24 \mathrm{~h}$. The virus yield was determined in MDBK cells with results expressed as $\mathrm{TCID}_{50} / \mathrm{ml}$. The compound PAA is a known anti-herpesvirus compound (Becker et al., 1977). As a positive control, the antiviral effect of PAA $(100 \mu \mathrm{mol} / \mathrm{l})$ on BoHV-1 infection in MDBK cells was evaluated in parallel with Kaempferol $(\mu \mathrm{mol} / \mathrm{l})$.

Time-of-addition assay. MDBK cells of 70-80\% confluent in 24well plates were infected with BoHV-1 at MOI of 1 . Kaempferol at a concentration of $100 \mu \mathrm{mol} / \mathrm{l}$ was added to cells at the indicated time point during virus infection. At 24 hours post infection (hpi) the virus yields were titrated in MDBK cells with results expressed as $\mathrm{TCID}_{50} / \mathrm{ml}$. The diagram in Fig. 2a shows four different experimental conditions.

Cell lysate preparation and Western blotting analysis. MDBK cells cultured in 60-mm dishes were mock infected with medium or infected with BoHV-1 at MOI of 10 along with or without Kaempferol. At $30 \mathrm{~min}$ post infection, the cells were washed and lysed with lysis buffer (1\% Triton X-100, $50 \mathrm{mmol} / \mathrm{l}$ sodium chloride, $1 \mathrm{mmol} / \mathrm{l}$ EDTA, $1 \mathrm{mmol} / \mathrm{l} \mathrm{EGTA,} 20 \mathrm{mmol} / \mathrm{l}$ sodium fluoride, $20 \mathrm{mmol} / \mathrm{l}$ sodium pyrophosphate, $1 \mathrm{mmol} / \mathrm{l}$ phenylmethylsulfonyl fluoride, $0.5 \mu \mathrm{g} / \mathrm{ml}$ leupeptin, $1 \mathrm{mmol} / \mathrm{l}$ benzamidine, and $1 \mathrm{mmol} / \mathrm{l}$ sodium orthovanadate in $20 \mathrm{mmol} / \mathrm{l}$ Tris- $\mathrm{HCl}, \mathrm{pH} \mathrm{8.0)}$ ). The cell lysates were then subjected to Western blotting analysis.

Detection of cytokines with ELISA. dU937 cells in 6-well plates were mock-treated with PBS or treated with LPS $(1 \mu \mathrm{g} / \mathrm{ml})$ in the absence or presence of Kaempferol at indicated concentrations for $24 \mathrm{~h}$. The medium was collected and subjected to the detection of cytokines IL-8, TNF- $\alpha$ and MIP-1 $\alpha$ with commercial ELISA kits from Boster Biological Technology (Hubei, China).

Statistical analysis. These studies were repeated 3 times and an asterisk denotes significant differences between vehicle and Kaempferol ( ${ }^{\star} \mathrm{P}<0.05$ and $\left.{ }^{* *} \mathrm{P}<0.01\right)$ as determined by the Student's $t$-test.

\section{Results}

\section{The antiviral effect of Kaempferol on BoHV-1 infection}

To assess the antiviral effect of Kaempferol on BoHV-1 replication, a concentration of $100 \mu \mathrm{mol} / \mathrm{l}$ that has no cytotoxicity to MDBK cells was selected by MTT assay (data not shown). MDBK cells were first pretreated with DMSO or Kaempferol at indicated concentrations of 25, 50 and $100 \mu \mathrm{mol} / \mathrm{l}$, then infected with BoHV-1 (MOI=1). The cells were treated with Kaempferol through the virus infection. At 24 hpi the virus yield was determined. As expected, Kaempferol significantly inhibited viral replication in a dose-dependent manner. Surprisingly, at the concentration of $100 \mu \mathrm{mol} / \mathrm{l}$, Kaempferol completely suppressed the virus replication, while at the concentration of 25 and $50 \mu \mathrm{mol} / \mathrm{l}$ it reduced the viral titer by $1.1 \mathrm{log}$ and $3.6 \mathrm{log}$, respectively (Fig. 1a). PAA is a specific inhibitor targeting the viral DNA polymerase (Becker et al., 1977). The antiviral effect of Kaempferol on BoHV-1 infection was further analyzed through comparison to PAA. Kaempferol demonstrated much stronger inhibitory effect on viral replication relative to PAA. PAA at a concentration of $100 \mu \mathrm{mol} / \mathrm{l} \mathrm{re-}$ 
(a)

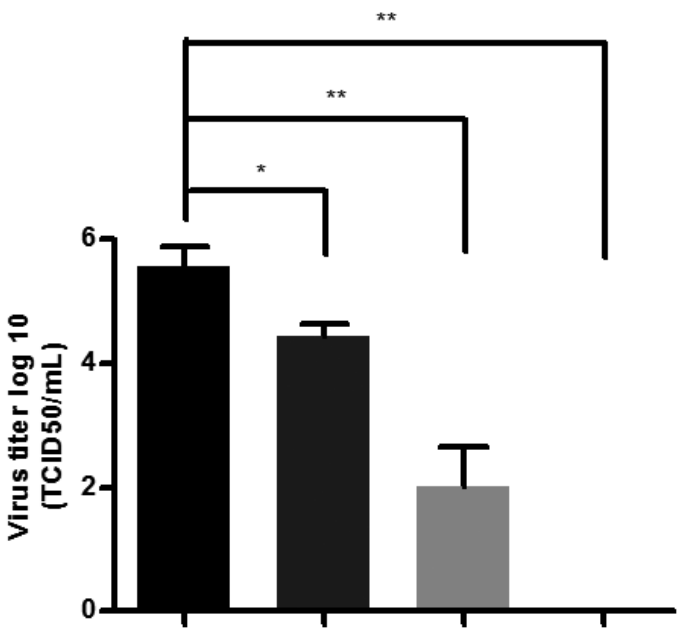

Kaempferol $(\mu \mathrm{M}): \quad 0$

25

50

100

(b)

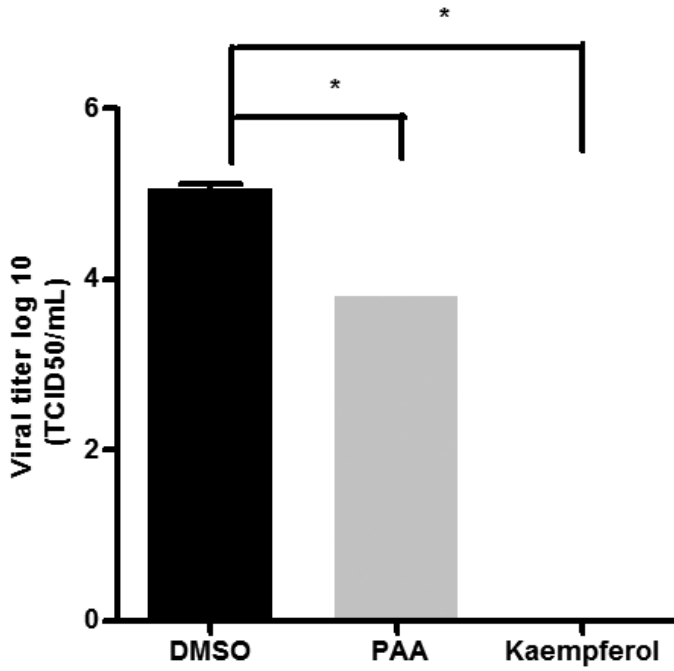

Fig. 1

Kaempferol inhibited BoHV-1 replication in MDBK cells (a) MDBK cells in 24-well plates were pretreated with DMSO control or Kaempferol at indicated concentrations for $1 \mathrm{~h}$, infected with BoHV-1 at MOI 1 for $1 \mathrm{~h}$ in the presence of Kaempferol. At $24 \mathrm{~h}$ after infection, cells together with medium were collected for virus titration. (b) MDBK cells in 24-well plates were pretreated with DMSO control or Kaempferol or PAA at indicated concentrations for $1 \mathrm{~h}$, then infected with BoHV-1 at MOI 1 for $1 \mathrm{~h}$ in the presence of Kaempferol or PAA. At $24 \mathrm{~h}$ after infection, cells together with medium were collected for virus titration. Data presented are mean \pm SD of three independent experiments. Significance was assessed by Student's $t$ test $\left({ }^{*}, P<0.05\right.$ and $\left.{ }^{* *}, P<0.01\right)$.

duced the virus titer by $\sim 1.3 \mathrm{log}$, while Kaempferol completely inhibited virus replication (Fig. 1b), which also validated the antiviral effect of Kaempferol.

To clarify which step(s) of BoHV-1 replication were affected by Kaempferol, a time-of-addition assay was performed. (a)

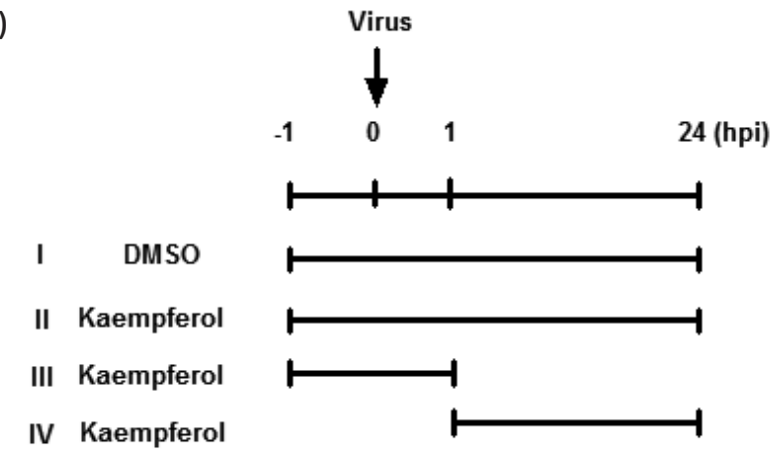

(b)

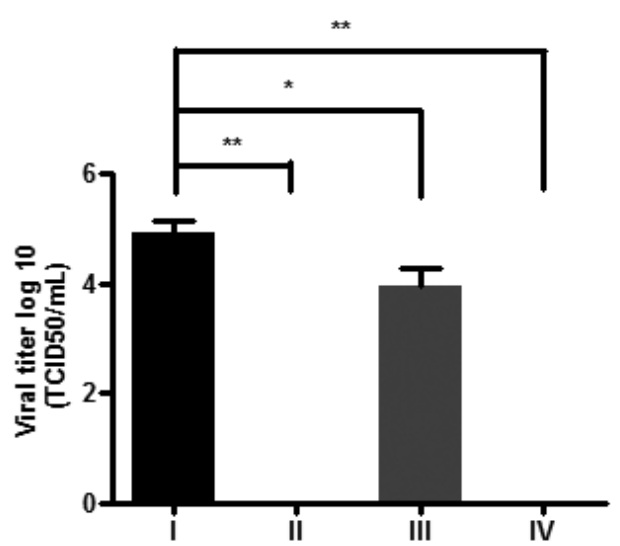

Fig. 2

(a) Diagram showing four different experimental conditions. I, DMSO treatment from -1 to $24 \mathrm{hpi}$. II, Kaempferol treatment from -1 to $24 \mathrm{hpi}$. III, Kaempferol treatment from -1 to $1 \mathrm{hpi}$. IV, Kaempferol treatment from 1 to $24 \mathrm{hpi}$. (b) Viral production of BoHV-1 under experimental conditions I to IV. Data presented are mean \pm SD of three independent experiments. Significance was assessed by Student's $t$ test $\left({ }^{*}, P<0.05\right.$ and $\left.^{* *}, P<0.01\right)$.

MDBK cells in 24-well plates were treated with Kaempferol at a concentration of $100 \mu \mathrm{mol} / \mathrm{l}$ in different manners as shown in Fig. 2a. The treatment of cells with Kaempferol at the postentry stages (III) still completely inhibited the virus replication (Fig. 2b), suggesting that Kaempferol may interrupt BoHV-1 infection mainly at the post-entry stage(s). When cells were exposed to Kaempferol at both virus binding and entry stages (II), the virus replication was still significantly inhibited, with $\sim 1 \log$ reduction compared to the control. This reduction may have been caused by the residual intracellular Kaempferol that would affect the virus replication at the post-entry stages.

Kaempferol inhibited Akt signaling in response to BoHV-1 infection

We have previously identified that BoHV-1 infection stimulated Akt signaling for efficient replication, and this 
BoHV-1

$-+-+-+-+$

$\begin{array}{lllllllll}\text { Kaempferol }(\mu M) & 0 & 0 & 2.5 & 2.5 & 25 & 25 & 50 & 50\end{array}$

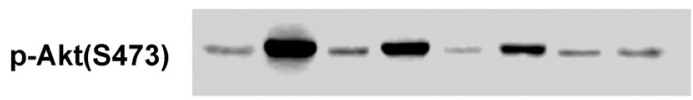

Akt

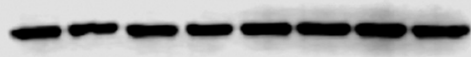

B-Actin
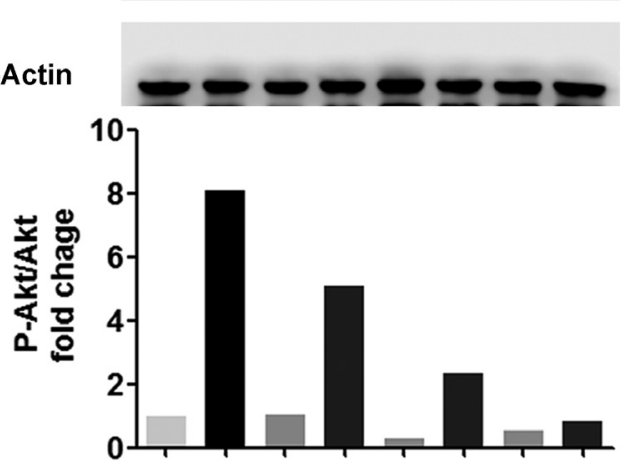

Fig. 3

Kaempferol interfered with Akt signaling following BoHV-1 infection in MDBK cells

MDBK cells were treated with or without Kaempferol at indicated concentrations for $1 \mathrm{~h}$, then infected with BoHV- 1 at MOI of 10 for $0.5 \mathrm{~h}$, along with the treatment of Kaempferol at corresponding concentrations. The cell lysates were prepared for Western blotting analysis by the detection of phospho-Akt, Akt and $\beta$-Actin. Quantitative analysis was performed with Image J software. These results are representative of three independent experiments.

signaling mainly affects the virus post-entry stages (Zhu et al., 2011). Therefore, the effect of Kaempferol on Akt signaling stimulated by BoHV-1 infection was evaluated. MDBK cells were infected with BoHV-1 (MOI = 10) along with the treatment with Kaempferol at concentrations of 50, 25 and $2.5 \mu \mathrm{mol} / \mathrm{l}$. As a result, Kaempferol diminished the activation of Akt signaling in response to BoHV-1 infection in a dosedependent manner (Fig. 3), suggesting that the interruption of Akt signaling is a potential mechanism for the antiviral effect of Kaempferol against BoHV-1 infection.

Kaempferol inhibited LPS-induced expression of proinflammatory cytokine TNF- $\alpha$ and chemokines IL-8 and MIP- $1 \alpha$

Monocytes/macrophages are one of the main sources that produce inflammatory cytokines and chemokines. LPS is a canonical stimulator for the induction of inflammatory cytokines. Here, the effect of Kaempferol on LPS-induced expression of pro-inflammatory cytokine TNF- $\alpha$, and the chemokines IL- 8 and MIP-1 $1 \alpha$ in dU937 cells was evaluated (a)

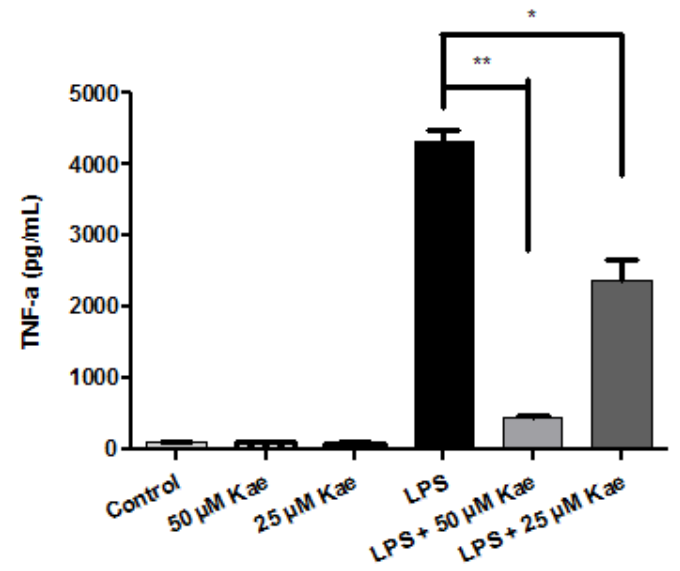

(b)

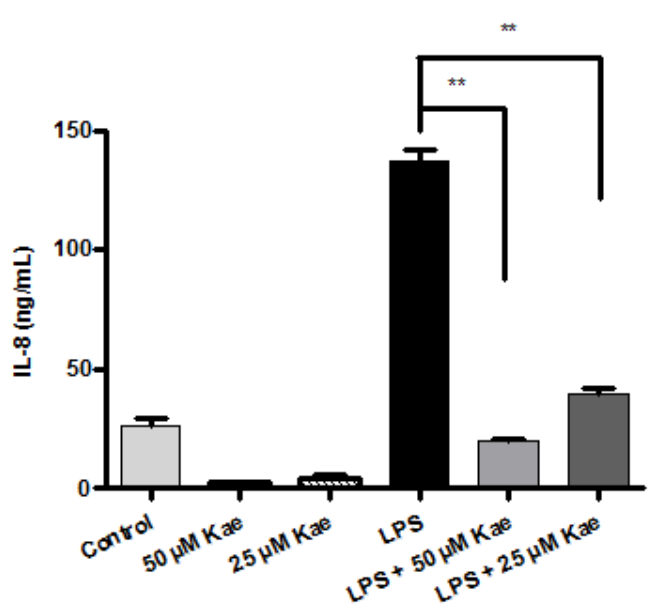

(c)

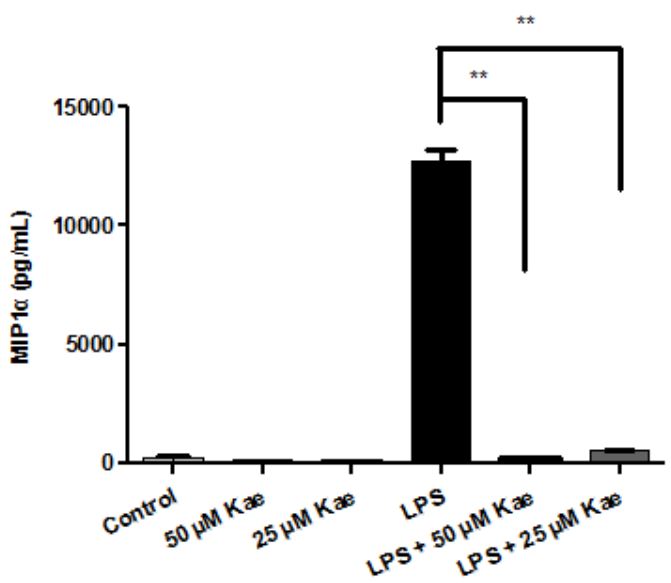

Fig. 4

Kaempferol inhibited the expression of (a) TNF- $\alpha$, (b) IL-8 and (c) MIP-1 $\alpha$ in macrophage-like dU937 cells

dU937 cells were mock stimulated with DMSO or stimulated with LPS ( $1 \mu \mathrm{g} /$ $\mathrm{ml}$ ) in the presence of Kaempferol at various concentrations. At $24 \mathrm{~h}$ post stimulation, the culture medium was collected for the detection of TNF- $\alpha$, IL- 8 and MIP- $1 \alpha$ with ELISA kits. Data presented are mean \pm SD of three independent experiments. Significance was assessed with Student's $t$ test $\left({ }^{*}, P<0.05\right.$ and $\left.{ }^{* *}, P<0.01\right)$. 
with commercial ELISA kit. dU937 cells were stimulated with LPS $(1 \mu \mathrm{g} / \mathrm{ml})$ in the presence of DMSO control or Kaempfer$\mathrm{ol}$ at indicated concentrations, respectively. The medium was collected for subsequent detection of indicated inflammatory cytokines and chemokines. The LPS-induced expression of TNF- $\alpha$, IL- 8 and MIP- $1 \alpha$ was inhibited by Kaempferol in a dose-dependent manner (Fig. 4). LPS induced the expression of TNF- $\alpha$ to a concentration of $4325.73 \mathrm{pg} / \mathrm{ml}$, while the treatment of cells with Kaempferol at a concentration of 25 and $50 \mu \mathrm{mol} / 1$ reduced TNF- $\alpha$ expression to a concentration of 2358.91 and $443.45 \mathrm{pg} / \mathrm{ml}$, respectively (Fig. 4a). LPS induced the IL-8 expression to a concentration of $137.47 \mathrm{ng} / \mathrm{ml}$, which was reduced to a concentration of 19.72 and $39.50 \mathrm{ng} /$ $\mathrm{ml}$ by 50 and $25 \mu \mathrm{mol} / \mathrm{l} \mathrm{Kaempferol,} \mathrm{respectively} \mathrm{(Fig.} \mathrm{4b).}$ LPS induced MIP-1 $\alpha$ expression to a concentration of $12732.4 \mathrm{pg} / \mathrm{ml}$, which was reduced by Kaempferol at a concentration of 25 and $50 \mu \mathrm{mol} / \mathrm{l}$ to a concentration of 220.37 and $536.69 \mathrm{ng} / \mathrm{ml}$, respectively (Fig. 4c). These data suggested that Kaempferol has strong capacity to lower the production of pro-inflammatory cytokine TNF- $\alpha$ and chemokines IL-8 and MIP-1 $\alpha$ in macrophages like dU937 cells.

\section{Discussion}

Plant-derived flavonoids and dietary isoflavones are a large group of natural phenylchromones found in fruits, vegetables, tea, soy foods, and herbs. Many flavonoids have been shown to possess multiple pharmacological effects such as antioxidative activity, anti-inflammatory and anticancer activities, as well as antiviral activities (Orhan et al., 2010; Kumar and Pandey, 2013). The flavonoid Kaempferol has been demonstrated to have antiviral activity against influenza viruses (H1N1 and H9N2), hepatitis B virus, Japanese encephalitis virus, enterovirus $71, \mathrm{HIV}-1$ and chikungunya virus in vitro (Li et al., 2008; Jeong et al., 2009a; Tsai et al., 2011; Zhang et al., 2012; Behbahani et al., 2014; Lani et al., 2015). But whether Kaempferol has anti-herpesvirus effect was unknown until now. In this study, we identified for the first time that Kaempferol had strong antiviral effect on BoHV-1 (Fig. 1). Since mentioned viruses belong to different families, it is highly possible that Kaempferol may have broad spectrum of antiviral effects. In view that Kaempferol showed a stronger antiviral activity relative to the known anti-herpesvirus drug PAA, this study may have important consequence to broaden the possiblity of getting an effective antiviral for herpesvirus infection.

Multiple evidence has indicated that Kaempferol could interrupt Akt signaling in multiple cell cultures, e.g. Kaempferol causes G2/M arrest in human hepatic cancer cells via induction of autophagy partially through Akt-dependent mechanism, and Kaempferol induces cell death in glioma cells partially through the inhibition of Akt signaling (Jeong et al., 2009b; Huang et al., 2013). These reports corroborated our result that Kaempferol inhibited Akt signaling in bovine kidney cells stimulated by BoHV-1 infection (Fig. 3). Thus, the damping of Akt signaling is a possible mechanism of the antiviral effect of Kaempferol.

Kaempferol could attenuate LPS-induced production of NO, PGE, TNF- $\alpha$, IL-1 $\beta$ and ROS in BV2 microglial cells (Park et al., 2011). Here, our results indicated that Kaempferol significantly suppressed the production of TNF- $\alpha$, IL-8 and MIP-1 $\alpha$ in macrophage-like dU937 cells, suggesting that Kaempferol also affects the inflammatory response in monocyte/macrophages. Thus Kaempferol may have potential antiinflammatory effect mediated by multiple cell types.

In summary, for the first time we revealed that Kaempferol has both antiviral effect against BoHV-1 infection and antiinflammatory effects mediated by macrophages.

Acknowledgments. We thank Dr. Leonard J. Bello, University of Pennsylvania, USA for the kindly providing BoHV-1 Colorado1 stain and MDBK cells. This research was supported by The National Key Research and Development Program of China with Grant No. 2016YFD0500704 and 2016YFD0500900, and Chinese National Science Foundation Grant (No. 31472172 and 31772743), the Priority Academic Program Development of Jiangsu Higher Education Institutions (PAPD).

\section{References}

Becker Y, Asher Y, Cohen Y, Weinberg-Zahlering E, Shlomai J (1977): Phosphonoacetic acid-resistant mutants of herpes simplex virus: effect of phosphonoacetic acid on virus replication and in vitro deoxyribonucleic acid synthesis in isolated nuclei. Antimicrob. Agents Chemother. 11, 919-922. https://doi.org/10.1128/ AAC.11.5.919

Behbahani M, Sayedipour S, Pourazar A, Shanehsazzadeh M (2014): In vitro anti-HIV-1 activities of kaempferol and kaempferol-7-O-glucoside isolated from Securigera securidaca. Res. Pharm. Sci. 9, 463-469.

Bielefeldt Ohmann H, Babiuk LA, Harland R (1991): Cytokine synergy with viral cytopathic effects and bacterial products during the pathogenesis of respiratory tract infection. Clin. Immunol. Immunopathol. 60, 153-170. https://doi. org/10.1016/0090-1229(91)90060-N

Huang WW, Tsai SC, Peng SF, Lin MW, Chiang JH, Chiu YJ, Fushiya S, Tseng MT, Yang, JS (2013): Kaempferol induces autophagy through AMPK and AKT signaling molecules and causes $\mathrm{G} 2 / \mathrm{M}$ arrest via downregulation of CDK1/cyclin B in SK-HEP-1 human hepatic cancer cells. Int. J. Oncol. 42, 2069-2077. https://doi.org/10.3892/ ijo.2013.1909

Jeong HJ, Ryu YB, Park SJ, Kim JH, Kwon HJ, Kim JH, Park KH, Rho MC, Lee, WS (2009a): Neuraminidase inhibitory activities of flavonols isolated from Rhodiola rosea roots and their in vitro anti-influenza viral activities. Bioorg. 
Med. Chem. 17, 6816-623. https://doi.org/10.1016/j. bmc.2009.08.036

Jeong JC, Kim MS, Kim TH, Kim YK (2009b): Kaempferol induces cell death through ERK and Akt-dependent downregulation of XIAP and survivin in human glioma cells. Neurochem. Res. 34, 991-1001. https://doi.org/10.1007/ s11064-008-9868-5

Jones C (2009): Regulation of Innate Immune Responses by Bovine Herpesvirus 1 and Infected Cell Protein 0 (bICP0). Viruses 1, 255-275. https://doi.org/10.3390/v1020255

Jones C, Chowdhury S (2007): A review of the biology of bovine herpesvirus type 1 (BHV-1), its role as a cofactor in the bovine respiratory disease complex and development of improved vaccines. Anim. Health. Res. Rev. 8, 187-205. https://doi.org/10.1017/S146625230700134X

Kumar AD, Bevara GB, Kaja LK, Badana AK, Malla RR (2016): Protective effect of 3-O-methyl quercetin and kaempferol from Semecarpus anacardium against $\mathrm{H} 2 \mathrm{O} 2$ induced cytotoxicity in lung and liver cells. BMC Complement. Altern. Med. 16, 376. https://doi.org/10.1186/s12906016-1354-Z

Kumar S, Pandey AK (2013): Chemistry and biological activities of flavonoids: an overview. Scientific World Journal 2013, 162750. https://doi.org/10.1155/2013/162750

La Gruta NL, Kedzierska K, Stambas J, Doherty PC (2007): A question of self-preservation: immunopathology in influenza virus infection. Immunol. Cell Biol. 85, 85-92. https://doi. org/10.1038/sj.icb.7100026

Lani R, Hassandarvish P, Chiam CW, Moghaddam E, Chu JJ, Rausalu K, Merits A, Higgs S, Vanlandingham D, Abu Bakar S, Zandi K (2015): Antiviral activity of silymarin against chikungunya virus. Sci. Rep. 5, 11421. https://doi. org/10.1038/srep11421

Li J, Huang H, Feng M, Zhou W, Shi X, Zhou P (2008): In vitro and in vivo anti-hepatitis $B$ virus activities of a plant extract from Geranium carolinianum L. Antiviral Res. 79, 114-120. https://doi.org/10.1016/j.antiviral.2008.03.001

Malazdrewich C, Ames TR, Abrahamsen MS, Maheswaran SK (2001): Pulmonary expression of tumor necrosis factor alpha, interleukin-1 beta, and interleukin- 8 in the acute phase of bovine pneumonic pasteurellosis. Vet. Pathol. 38, 297-310. https://doi.org/10.1354/vp.38-3-297

Muylkens B, Thiry J, Kirten P, Schynts F, Thiry E (2007): Bovine herpesvirus 1 infection and infectious bovine rhinotracheitis. Vet. Res. 38, 181-209. https://doi.org/10.1051/ vetres:2006059

Orhan DD, Ozcelik B, Ozgen S, Ergun F (2010): Antibacterial, antifungal, and antiviral activities of some flavonoids.
Microbiol. Res. 165, 496-504. https://doi.org/10.1016/j. micres.2009.09.002

Park SE, Sapkota K, Kim S, Kim H, Kim SJ (2011): Kaempferol acts through mitogen-activated protein kinases and protein kinase B/AKT to elicit protection in a model of neuroinflammation in BV2 microglial cells. Br. J. Pharmacol. 164, 1008-1025. https://doi.org/10.1111/j.14765381.2011.01389.x

Risalde MA, Molina V, Sanchez-Cordon PJ, Pedrera M, Panadero R, Romero-Palomo F, Gomez-Villamandos JC (2011): Response of proinflammatory and anti-inflammatory cytokines in calves with subclinical bovine viral diarrhea challenged with bovine herpesvirus-1. Vet. Immunol. Immunopathol. 144, 135-143. https://doi.org/10.1016/j. vetimm.2011.07.022

Rivera-Rivas JJ, Kisiela D, Czuprynski CJ (2009): Bovine herpesvirus type 1 infection of bovine bronchial epithelial cells increases neutrophil adhesion and activation. Vet. Immunol. Immunopathol. 131, 167-76. https://doi. org/10.1016/j.vetimm.2009.04.002

Tikoo SK, Campos M, Babiuk LA (1995): Bovine herpesvirus 1 (BHV-1): biology, pathogenesis, and control. Adv. Virus Res. 45, 191-223. https://doi.org/10.1016/S0065-3527(08)60061-5

Tsai FJ, Lin CW, Lai CC, Lan YC, Lai CH, Hung CH, Hsueh KC, Lin TH, Chang HC, Wan L, Sheu JJ, Lin YJ (2011): Kaempferol inhibits enterovirus 71 replication and internal ribosome entry site (IRES) activity through FUBP and HNRP proteins. Food Chem. 128, 312-322. https://doi. org/10.1016/j.foodchem.2011.03.022

Wang T, Liu YP, Wang T, Xu BQ, Xu B (2017): ROS feedback regulates the microRNA-19-targeted inhibition of the p47phox-mediated LPS-induced inflammatory response. Biochem. Biophys. Res. Commun. 489, 361-368. https:// doi.org/10.1016/j.bbrc.2017.05.022

Zhang T, Wu Z, Du J, Hu Y, Liu L, Yang F, Jin Q (2012): Anti-Japanese-encephalitis -viral effects of kaempferol and daidzin and their RNA-binding characteristics. PLoS One 7, e30259. https://doi.org/10.1371/journal.pone.0030259

Zhu L, Ding X, Zhu X, Meng S, Wang J, Zhou H, Duan Q, Tao J, Schifferli DM, and Zhu G (2011): Biphasic activation of PI3K/Akt and MAPK/Erk1/2 signaling pathways in bovine herpesvirus type 1 infection of MDBK cells. Vet. Res. 42, 57. https://doi.org/10.1186/1297-9716-42-57

Zhu L, Yuan C, Zhang D, Ma Y, Ding X, Zhu, G (2016): BHV-1 induced oxidative stress contributes to mitochondrial dysfunction in MDBK cells. Vet. Res. 47, 47. https://doi. org/10.1186/s13567-016-0332-2 